\title{
Contribution of mineral $N$ to young grapevine in the presence or absence of cover crops
}

\author{
Gustavo Brunetto ${ }^{1 *}$, Felipe Lorensini ${ }^{1}$, Carlos Alberto Ceretta $^{1}$, Paulo Ademar Avelar Ferreira ${ }^{1}$, \\ Rafael da Rosa Couto ${ }^{1}$, Lessandro De Conti ${ }^{1}$, Marlise Nara Ciotta ${ }^{2}$, Matheus Kulmann ${ }^{1}$, \\ Rodrigo Otávio Schneider ${ }^{1}$, Luiza Michelon Somavilla ${ }^{1}$, Tadeu Luis Tiecher ${ }^{1}$, Sandro \\ Giacomini $^{1}$, George Wellington Bastos de Melo ${ }^{3}$, Corina Luisa Videira de Abreu F. Carranca ${ }^{4}$
}

${ }^{1}$ Universidade Federal de Santa Maria, Centro de Ciências Rurais, Programa de Pós-Graduação em Ciência do Solo, Avenida Roraima, 1000, C.P. 221, CEP 97105-900, Santa Maria, RS, Brazil. ${ }^{2}$ Empresa de Pesquisa Agropecuária e Extensão Rural de Santa Catarina (EPAGRI), Rua João Araújo Lima, 102, Bairro Jardim Caiçara, CEP 88600-000, São Joaquim, SC, Brazil. ${ }^{3}$ Embrapa Uva e Vinho, Rua Livramento, $n^{\circ} 515$ Caixa Postal: 130 CEP: 95700-000 - Bento Gonçalves - RS, Brazil. ${ }^{4}$ Instituto Nacional de Investigação Agrária e Veterinária, Quinta do Marquês, Av. República, Nova Oeiras, 2784-505 Oeiras, Portugal. *Corresponding author: brunetto.gustavo@gmail.com.

\begin{abstract}
The presence of cover crops in vineyards may decrease the availability of nitrogen $(\mathrm{N})$ derived from fertilizer to grapevines. The present study aimed to evaluate the recovery of urea $-{ }^{15} \mathrm{~N}$ and growth of young grapevines with and without natural vegetation in plant rows. The study was conducted in southern Brazil on one-year-old Chardonnay grapevines grown in soils with and without cover crops. The grapevines were subjected to the application of $40 \mathrm{~kg} \mathrm{~N} \mathrm{ha}^{-1}$ in the form of urea- ${ }^{15} \mathrm{~N}$ at $3 \%{ }^{15} \mathrm{~N}$ atom excess. Dry matter yield, total $\mathrm{N}$ and fertilizer $\mathrm{N}$ were assessed in grapevines and soil layers. A small amount of $\mathrm{N}$ that is applied during the growing season of the grapevines is readily assimilated by the plants. The maintenance of cover crops in young vineyards may favor the maintenance of higher levels of $\mathrm{N}$ in the subsurface layers of the soil, contributing to the nutrition of the grapevines in the following growth cycles. The presence of cover crops reduced the importance of nitrogen fertilization in the growth cycle of grapevines because a large part of $\mathrm{N}$ absorbed by grapevines was derived from other sources. Nitrogen derived from the fertilizer applied to the soil in the presence or absence of cover crops was mainly concentrated in the newly-formed vegetative grapevine organs (leaves and shoots).
\end{abstract}

Keywords: Urea $-{ }^{15} \mathrm{~N}, \mathrm{~N}$ recovery, plant $\mathrm{N}$ distribution, residual- ${ }^{15} \mathrm{~N}$, Vitis vinifera 


\section{Introduction}

The presence of spontaneous or implanted cover crops in vineyards may contribute to the increase of soil organic matter, soil aggregate stability and soil microbial activity, when managed by mowing. Growing plants and residues deposited on the soil surface contribute to the dissipation of kinetic energy of raindrops and the reduction of soil particle breakdown by water erosion, also promoting nutrient release in soil (Brunetto et al., 2011; Brunetto et al., 2014; Rumpel et al., 2015). Cover crops in the grapevine planting rows are sometimes desiccated with post-emergent herbicides (Giese et al., 2014) to avoid their competition for water and nutrients, especially $\mathrm{N}$, compromising the proper growth of grapevines, especially that of young plants. Permanent cover cropping is currently increasing in vineyards worldwide because of its beneficial effects to soil and grapevine health, but studies evaluating their competitive effects on grapevines have been conducted primarily in non-irrigated vineyards.

Urea has been used as a mineral nitrogen $(\mathrm{N})$ fertilizer in vineyards. This $\mathrm{N}$ fertilizer is rapidly hydrolyzed in the soil by the extracellular enzyme urease produced by microorganisms such as soil fungi, bacteria and actinomycetes. Formed ammonium carbonate $\left(\mathrm{NH}_{4}^{+}\right)_{2} \mathrm{CO}_{3}$ is not stable in the soil and is decomposed into bicarbonate anion $\left(\mathrm{HCO}_{3}^{-}\right)$, hydroxide ion $\left(\mathrm{OH}^{-}\right)$and ammonium $\left(\mathrm{NH}_{4}{ }^{+} \mathrm{N}\right)$ in the presence of soil water. $\mathrm{HCO}_{3}{ }^{-}$is also decomposed into carbon dioxide $\left(\mathrm{CO}_{2}\right)$ and $\mathrm{OH}^{-}$. The loss of ammonia $\left(\mathrm{NH}_{3}\right)$ to the atmosphere may occur with the reaction of $\mathrm{NH}_{4}{ }^{+}-\mathrm{N}$ with $\mathrm{OH}^{-}$, especially when the soil $\mathrm{pH}$ is not higher than 8 (Singh et al., 2013), but part of the $\mathrm{NH}_{4}^{+}-\mathrm{N}$ is simultaneously converted into nitrite $\left(\mathrm{NO}_{2}^{-}-\mathrm{N}\right)$ and nitrate $\left(\mathrm{NO}_{3}^{-}-\mathrm{N}\right)$ through biological oxidation (Ladan and Jacinthe, 2017). $\mathrm{NO}_{3}^{-}-\mathrm{N}$ in the soil is rapidly absorbed by cover crops, thus decreasing its concentration in the soil and the amount available for grapevine uptake (Pérez-Álvarez et al., 2015). If this happens, less transport and accumulation of $\mathrm{N}$ in annual organs of grapevines is expected (Glad et al., 1994). With the elimination of cover crops in the planting rows of young grapevines by desiccation, a higher concentration of $\mathrm{NO}_{3}-\mathrm{N}$ derived from urea is expected in soil, thus promoting greater $\mathrm{N}$ recovery by young plants. However, when $\mathrm{NO}_{3}^{-}-\mathrm{N}$ is not absorbed by the grapevines, it may be lost by leaching, especially in soils with sandy texture, in particular when associated with a high volume of rainfall (Brunetto et al., 2006a, b; Barlow et al., 2009; Lorensini et al., 2012).

The ${ }^{15} \mathrm{~N}$ isotope has been used as a tracer in studies of plant $\mathrm{N}$ recovery and accumulation in plant organs (Menino et al., 2007; Neto et al., 2008; Brunetto et al., 2014), because it enables an accurate tracking of the amount of fertilizer $\mathrm{N}$ absorbed and its fractionation in plant organs. Intercropping vineyards with cover crops has been used but information on its potential competition is scarce. The present study aimed to evaluate the recovery of $\mathrm{N}$ derived from urea- ${ }^{15} \mathrm{~N}$ applied to the soil by young grapevines, in the presence or absence of cover crops in the planting rows under irrigation system.

\section{Material and Methods}

\subsection{Description of the experiment}

The experiment was conducted from July 2011 to July 2012 in a vineyard located in the city of Santana do Livramento, located in the Campanha Gaúcha region of the state of Rio Grande do Sul, southern Brazil (Latitude $30^{\circ} 49^{\prime} 7.82$ 'S; longitude 55 27'2.65”'W). The climate is humid subtropical (Cfa) according to Köppen classification (Köppen and Geiger, 1928). The annual temperature varied from 11.9 to $23.5{ }^{\circ} \mathrm{C}$ and the annual rainfall was $1599 \mathrm{~mm}$. Data of temperature, rainfall and insolation measured during the experimental period are presented in Table 1. 
Table 1. Air temperature, accumulated rainfall and average insolation during the experimental period in Santana do Livramento, state of Rio Grande do Sul, Brazil.

\begin{tabular}{cccccc}
\hline Year/Month & Minimum & $\begin{array}{c}\text { Air temperature } \\
\text { Mean } \\
{ }^{\circ} \mathrm{C}\end{array}$ & Maximum & Rainfall & Insolation \\
\hline 2011 & & & & mm & hours \\
\hline October & 12.2 & 16.8 & 22.4 & 154.5 & 227.9 \\
November & 14.3 & 20.5 & 27.6 & 54.1 & 283.2 \\
December & 15.3 & 21.4 & 28.3 & 44.9 & 283.7 \\
& & & & & \\
January & 17.3 & 24.6 & 32.5 & 18.7 & 315.6 \\
February & 18.9 & 23.9 & 29.9 & 220.5 & 218.5 \\
March & 15.8 & 21.6 & 27.8 & 58.5 & 278.3 \\
April & 12.7 & 17.3 & 23.1 & 147.5 & 204.6 \\
May & 12 & 16.4 & 22.4 & 13.1 & 200.8 \\
June & 8.2 & 12.8 & 17.3 & 77.7 & 144.5 \\
July & 5 & 9.6 & 15.4 & 32.2 & 203.1 \\
\hline
\end{tabular}

The soil is classified as Typic Hapludalf, according to Soil Survey Staff (2006). Main physical (Embrapa, 1997) and chemical (Tedesco et al., 1995) characteristics of the soil in the $0-20 \mathrm{~cm}$ layer are presented in Table 2 .

Table 2. Main physical and chemical characteristics of the soil in the experimental site at $0-20 \mathrm{~cm}$.

\begin{tabular}{|c|c|c|}
\hline Attribute & Unit & $0-20 \mathrm{~cm}$ \\
\hline Clay & $\mathrm{g} \mathrm{kg}^{-1}$ & 83 \\
\hline Silt & $\mathrm{g} \mathrm{kg}^{-1}$ & 178 \\
\hline Sand & $\mathrm{g} \mathrm{kg}^{-1}$ & 740 \\
\hline Organic matter & $\mathrm{g} \mathrm{kg}^{-1}$ & 10.7 \\
\hline $\mathrm{pH}_{(\mathrm{H} 2 \mathrm{O})}$ & - & 5.2 \\
\hline $\mathrm{NH}_{4}{ }^{+}-\mathrm{N}$ & $\mathrm{mg} \mathrm{kg}^{-1}$ & 8.6 \\
\hline $\mathrm{NO}_{3}{ }^{-}-\mathrm{N}$ & $\mathrm{mg} \mathrm{kg}^{-1}$ & 20.9 \\
\hline Total N & $\mathrm{mg} \mathrm{kg}^{-1}$ & 591.4 \\
\hline Available phosphorus & $\mathrm{mg} \mathrm{kg}^{-1}$ & 11.0 \\
\hline Available potassium & $\mathrm{mg} \mathrm{kg}^{-1}$ & 90.8 \\
\hline Exchangeable calcium & $\mathrm{cmol}_{\mathrm{C}} \mathrm{kg}^{-1}$ & 1.8 \\
\hline Exchangeable magnesium & $\mathrm{cmol}_{\mathrm{ckg}}{ }^{-1}$ & 1.4 \\
\hline Exchangeable aluminum & $\mathrm{cmol}_{\mathrm{c}} \mathrm{kg}^{-1}$ & 0.0 \\
\hline
\end{tabular}


The experiment was conducted in a non-anthropic, natural grassland field, without any cultivation history. The preparation of the area for the experiment started in the first half of July 2011, when we applied $3800 \mathrm{~kg} \mathrm{ha}^{-1}$ of lime to raise the soil $\mathrm{pH}\left(\mathrm{H}_{2} \mathrm{O}\right)$ to 6.0 and $60 \mathrm{~kg} \mathrm{P}_{2} \mathrm{O}_{5}$ ha $^{-1}$ as triple superphosphate to raise the available soil phosphorus (P). Potassium (K) was not applied because soil available $\mathrm{K}$ was high (CQFS$\mathrm{RS} / \mathrm{SC}$ 2004). Lime and fertilizer $P$ were incorporated into the soil by plowing at a $20 \mathrm{~cm}$ depth using a disc plow, followed by harrowing. In the second half of July 2011, pits were open in rows and the Chardonnay grapevines (Vitis vinifera L.) were transplanted and grafted onto rootstock $110 \mathrm{R}$ at a density of 4000 plants per hectare $(1.0 \mathrm{~m}$ between plants in the row and $2.5 \mathrm{~m}$ inter-row spacing). The vineyard conduction system was espalier.

In the first half of October 2011, the treatments were defined as follows: 1) grapevines were planted in rows with natural intercropping residues, and 2) grapevines were planted under herbicide application (cover crops were eradicated by desiccation using glyphosate, a non-residual systemic herbicide, and residues were removed from the soil surface). In the desiccation treatment, the herbicide was applied twice during the experimental period, at a distance of $50 \mathrm{~cm}$ from each side of grapevines, using $3 \mathrm{~L} \mathrm{ha}^{-1}$ of glyphosate in a total volume of $200 \mathrm{~L}$ of water ha- ${ }^{-1}$. The cover crop species that predominated as natural vegetation in the grapevine rows were a mixture of grasses and Fabaceae plants: Paspalum notatun, Lolium multiflorum, Bromus auleticus, Desmodium spp. and Vicia sativa. Mowing was done throughout the whole experimental area to keep the vegetation at a $10 \mathrm{~cm}$ height, and residues were left on the soil surface.

The experimental design was randomized blocks with three replications. Each replication consisted of five plants and the 3 central plants were evaluated.
In the second half of October 2011, $40 \mathrm{~kg} \mathrm{~N} \mathrm{ha}^{-1}$ (regional recommendation for young grapevines in soils with less than $2.5 \%$ organic matter content - CQFS$\mathrm{RS} / \mathrm{SC}, 2004)$ was applied in the urea- ${ }^{15} \mathrm{~N}$ form $(44 \%$ N) at $3 \%{ }^{15} \mathrm{~N}$ atom excess, corresponding to $10 \mathrm{~g} \mathrm{~N}$ plant $^{-1}$. Urea was applied on the soil surface, without incorporation, at a distance of $50 \mathrm{~cm}$ from the grapevines. After the distribution of urea, irrigation was provided at a rate of $14.5 \mathrm{~mm}$ of water.

\subsection{Plant and soil sampling and analysis}

Young shoots and leaves (limbo and petiole) were collected in December 2011 (two months after N application) and in March 2012 (five months after N application), respectively, in the central grapevines in each replication and for both treatments. In July 2012, grapevines in all plots were cut close to the soil surface and separated into leaves, shoots and trunk. Grapevine roots were manually collected in a trench of $1.0 \times 1.0 \times 0.6 \mathrm{~m}$ (length, width and depth). In the cover crop treatment, cover crops were also cut close to the soil surface $(10 \mathrm{~cm}$ height) and separated manually into leaves and shoots. The separation of grapevine roots from the cover crop roots was also done manually. All roots were washed in running water and then in distilled water. All grapevine and cover crop material was washed and dried in an oven with forced-air circulation (MA 035/1, Marconi, Piracicaba, BR) at $65{ }^{\circ} \mathrm{C}$ until constant weight. Then, plant organs were ground and reserved for analysis.

The soil samples were collected at 0-5, 5-10, 10-20, 20-30, 30-40, 40-50 and 50-60 cm layers, with three subsamples per repetition. Soil samples were air dried, ground using an agate mortar, sieved $(<0.5 \mathrm{~mm})$ to remove rock fragments and reserved for analysis.

Samples of plant tissue and soil were analyzed for $\mathrm{N}$ concentration and ${ }^{15} \mathrm{~N}$ enrichment by dry combustion 
and mass spectrometry (20/20 Hydra model, PDZ Europa, Crewe, UK), respectively.
The atom $\%{ }^{15} \mathrm{~N}$ excess in soil and plant samples and ${ }^{15} \mathrm{~N}$ fertilizer was calculated according to equation 1 :

\section{Atom ${ }^{15} \mathrm{~N}$ excess in sample or fertilizer $(\%)=$ atom $\%{ }^{15} \mathrm{~N}$ in sample or fertilizer $-0.3663 \%$ (1)}

where $0.3663 \%$ is the ${ }^{15} \mathrm{~N}$ natural abundance in the atmosphere.
The nitrogen derived from fertilizer ( $\% \mathrm{Ndff})$ was calculated using equations 2 and 3 , respectively:

Nitrogen derived from fertilizer $(\%)=\frac{\text { atom } \%{ }^{15} N \text { excess in sample }}{\text { atom } \%{ }^{15} N \text { excess in fertilizer }} \times 100$

Nitrogen derived from fertilizer $(m g)=$ total $N$ in sample $(m g) \times \frac{\text { atom } \%{ }^{15} N \text { excess in sample }}{\text { atom } \%{ }^{15} N \text { excess in fertilizer }}$

\subsection{Statistical treatment of the data}

The data was subjected to analysis of variance, and when this analysis indicated statistically significant treatment effects, it was subjected to the Scott-Knott's means comparison test $(\mathrm{p}<0.05)$ (Ferreira 2011).

\section{Results}

\section{1. ${ }^{15} \mathrm{~N}$ distribution in the Chardonnay grapevine}

The highest dry matter (DM) yield and total $\mathrm{N}$ accumulated in sampled shoots $\left(\mathrm{mg} \mathrm{plant}^{-1}\right)$ was observed in grapevines grown in the soil with crop residues (Table 3). However, the highest atom \% ${ }^{15} \mathrm{~N}$ excess and $\% \mathrm{Ndff}$ were observed in shoots of grapevines planted in soil without plant residues (desiccated plants).

Five months after N application (March 2012), the percentage of total $\mathrm{N}$, atom ${ }^{15} \mathrm{~N}$ excess and $\mathrm{Ndff}$ in the grapevines leaves did not show significant differences between treatments (Table 3). Comparing the ${ }^{15} \mathrm{~N}$ enrichment in grapevines planted in both treatments, it was much higher in leaves than shoots.
Results obtained in July 2012, nine months after N application showed a different response to treatments (Table 4). We observed significant reduction in the DM yield of sampled grapevine organs (except leaves) and their fertilizer $\mathrm{N}$ recovery (Table 4). The amount of Ndff ( $g$ plant $\left.{ }^{-1} \mathrm{DM}\right)$ in grapevine shoots, trunk and roots in covered rows was reduced by $24 \%, 36 \%$ and $38 \%$, respectively, which is significantly lower than the accumulated Ndff in grapevines grown in the desiccated area. At this growth phase, leaves and shoots of grapevines grown with and without cover crops had higher percentages of atom ${ }^{15} \mathrm{~N}$ excess and Ndff in relation to the trunk and roots (Table 4).

Grapevines showed \%Ndff lower than $7.0 \%$ in each organ, either in the presence or absence of cover crops in the planting rows, indicating that more than $93 \%$ of $\mathrm{N}$ in each plant organ was derived from sources other than the fertilizer $\mathrm{N}$ applied in the season (Table 4).

\section{2. ${ }^{15} \mathrm{~N}$ distribution in the soil}

The highest atom $\%{ }^{15} \mathrm{~N}$ excess and $\% \mathrm{Ndff}$ in soil with and without cover crops was observed in the uppermost soil layer (depth of 0-5 cm) compared with deeper 
layers, and the values did not vary with the treatments (Table 5). From 5-10 $\mathrm{cm}$ to deeper soil layers, the $\%$ Ndff decreased for both treatments, but was significantly higher in the presence of natural vegetation.

\section{Discussion}

The highest dry matter yield and $\mathrm{N}$ accumulation in grapevines grown in the soil with crop residues proves that for early grapevine growth, i.e., five months after transplanting (December 2011), the presence of cover crops is a positive strategy for grapevine growth. Cover crops contributed to increase nutrient availability by the exudation of organic compounds to the rhizosphere (Zuo and Zhang 2008) which was apparently used by associated perennial crop. The highest atom $\%{ }^{15} \mathrm{~N}$ excess and $\%$ Ndff percentages in shoots of grapevines grown in soil without residues are attributed to the lower growth of these grapevines compared with plants in covered rows, where a higher dilution effect of ${ }^{15} \mathrm{~N}$ concentration in plants may have occurred. However, an absence of competition for mineral ${ }^{15} \mathrm{~N}$ fertilizer in desiccated rows may also have contributed to the highest ${ }^{15} \mathrm{~N}$ concentration in grapevines planted in the absence of cover crops.

Table 3. Dry matter, total $\mathrm{N}$, atom $\%{ }^{15} \mathrm{~N}$ excess and $\mathrm{N}$ derived from fertilizer (Ndff) in Chardonnay grapevine shoots and leaves sampled in December 2011 (two months after $\mathrm{N}$ application) and March 2012 (five months after $\mathrm{N}$ application), respectively.

\begin{tabular}{|c|c|c|c|c|c|c|}
\hline & \multirow{2}{*}{$\begin{array}{l}\text { Dry matter } \\
\left.\qquad \text { (g grapevine }^{-1}\right)\end{array}$} & \multicolumn{2}{|c|}{ Total N } & \multirow[t]{2}{*}{$\begin{array}{c}\text { Atom } \%{ }^{15} \mathrm{~N} \\
\text { excess }\end{array}$} & \multicolumn{2}{|c|}{ Ndff } \\
\hline & & $(\% \mathrm{DM})$ & $\begin{array}{c}(\mathrm{mg} \\
\left.\text { grapevine }^{-1}\right)\end{array}$ & & $\begin{array}{l}\text { (\% of total } \mathrm{N} \text { in the } \\
\text { organ) }\end{array}$ & (mg grapevine $^{-1}$ ) \\
\hline \multicolumn{7}{|c|}{ Shoots (December 2011) } \\
\hline Cover crops & $4.11 \pm 2.98$ & $2.64 \pm 0.06$ & $107.65 \pm 76.45$ & $0.029 \pm 0.003$ & $0.97 \pm 0.09$ & $1.01 \pm 0.61$ \\
\hline Desiccation & $2.28 \pm 1.14$ & $2.80 \pm 0.11$ & $63.24 \pm 30.55$ & $0.050 \pm 0.028$ & $1.68 \pm 0.95$ & $0.90 \pm 0.38$ \\
\hline Significance & * & ns & * & * & * & ns \\
\hline \multicolumn{7}{|c|}{ Leaves- (March 2012) } \\
\hline Cover crops & nd & $2.60 \pm 0.09$ & nd & $0.224 \pm 0.029$ & $7.46 \pm 0.98$ & nd \\
\hline Desiccation & nd & $2.97 \pm 0.05$ & nd & $0.233 \pm 0.054$ & $7.78 \pm 1.79$ & nd \\
\hline Significance & & ns & & ns & ns & \\
\hline
\end{tabular}

$\mathrm{ns}, *=\mathrm{F}$-values non-significant $(\mathrm{p}>0.05)$ and significant $(\mathrm{p}<0.05)$, respectively; mean \pm standard errors; $\mathrm{nd}=$ not determined

The percentage of all $\mathrm{N}$ forms evaluated in the grapevines leaves did not show significant differences between treatments, which indicates that leaf sampling at this phase is not a good indicator for differentiating between $\mathrm{N}$ sources in young grapevines. The ${ }^{15} \mathrm{~N}$ enrichment was higher in leaves than in shoots, meaning that leaves acted as a more efficient $\mathrm{N}$ darin for the fertilizer $\mathrm{N}$ applied in the season. As there was no change in leaf ${ }^{15} \mathrm{~N}$ enrichment between 
treatments in the first 5 months, this means that desiccation is not necessary during this period and vegetation may grow naturally. In addition to not affecting the uptake of $\mathrm{N}$ by grapevines, cover crops contribute to soil conservation by dissipating the kinetic energy of raindrops in the soil, reducing runoff (Cardoso et al., 2013; Abrantes et al., 2015).

The reduction in the DM yield of grapevines, fertilizer $\mathrm{N}$ recovery, and amount of Ndff in the treatment with covered rows could be due to the competition with cover crops. A similar result was observed by Celette et al. (2009) who found that the presence of an intercrop (grass) significantly reduced $\mathrm{N}$ accumulation in shoots of grapevine during the year due to the competition for soil wa- ter and $\mathrm{N}$. This reduction varied markedly between years (Celette et al., 2009) but it was more pronounced during dry years. Intercrop reduced grapevine growth of the year but also the potential growth for the following year by decreasing nitrogen perennial reserves. The higher percentages of atom ${ }^{15} \mathrm{~N}$ excess and Ndff in leaves and shoots of grapevines could be due to the $\mathrm{N}$ mobilization to the meristhematic plant organs, followed by rapid cell division (Conradie 1990; Brunetto et al., 2006a, b). Thus, leaves and shoots act as $\mathrm{N}$ drain during the vegetative growth of young grapevines (Zapata et al., 2004), as observed by Menino et al. (2007) and Neto et al. (2008), both in Portugal, for young non-bearing orange trees (Citrus sinensis L.) and deciduous fruit trees (Pyrus communis $L$ ), respectively.

Table 4. Dry matter, total $\mathrm{N}$, atom $\%{ }^{15} \mathrm{~N}$ excess and $\mathrm{N}$ derived from fertilizer (Ndff) in Chardonnay grapevine organs sampled in July 2012, nine months after transplanting.

\begin{tabular}{|c|c|c|c|c|c|c|c|}
\hline & & \multirow{2}{*}{$\begin{array}{l}\text { Dry matter } \\
\left(\mathrm{g} \mathrm{DM} \mathrm{plant}^{-1}\right)\end{array}$} & \multicolumn{2}{|c|}{ Total N } & \multirow[t]{2}{*}{$\begin{array}{c}\text { Atom } \%{ }^{15} \mathrm{~N} \\
\text { excess }\end{array}$} & \multicolumn{2}{|r|}{ Ndff } \\
\hline & & & $(\% \mathrm{DM})$ & (g plant $\left.{ }^{-1} \mathrm{DM}\right)$ & & $\begin{array}{l}\text { (\% of total } \mathrm{N} \\
\text { in the organ) }\end{array}$ & $\left(\mathrm{g} \mathrm{plant}^{-1} \mathrm{DM}\right)$ \\
\hline \multirow{3}{*}{ Leaves } & Cover crops & $12.34 \pm 8.13$ & $1.45 \pm 0.06$ & $181.91 \pm 123.62$ & $0.20 \pm 0.034$ & $6.82 \pm 1.10$ & $11.97 \pm 7.34$ \\
\hline & Desiccation & $12.53 \pm 4.13$ & $1.63 \pm 0.13$ & $206.72 \pm 81.11$ & $0.21 \pm 0.041$ & $6.93 \pm 1.32$ & $14.71 \pm 7.85$ \\
\hline & Significance & ns & ns & * & ns & ns & * \\
\hline \multirow{3}{*}{ Shoots } & Cover crops & $16.38 \pm 10.00$ & $0.71 \pm 0.06$ & $113.18 \pm 67.30$ & $0.20 \pm 0.031$ & $6.51 \pm 1.03$ & $7.47 \pm 5.02$ \\
\hline & Desiccation & $27.17 \pm 11.43$ & $0.70 \pm 0.10$ & $170.08 \pm 60.84$ & $0.19 \pm 0.033$ & $6.39 \pm 0.94$ & $11.04 \pm 5.14$ \\
\hline & Significance & $*$ & ns & $*$ & ns & ns & * \\
\hline \multirow{3}{*}{ Trunk } & Cover crops & $34.26 \pm 3.01$ & $0.81 \pm 0.01$ & $278.51 \pm 28.06$ & $0.15 \pm 0.014$ & $4.87 \pm 0.45$ & $13.60 \pm 2.29$ \\
\hline & Desiccation & $45.49 \pm 10.27$ & $0.76 \pm 0.10$ & $339.22 \pm 34.74$ & $0.15 \pm 0.029$ & $4.97 \pm 1.06$ & $16.63 \pm 2.32$ \\
\hline & Significance & $*$ & ns & * & ns & ns & * \\
\hline \multirow{3}{*}{ Roots } & Cover crops & $20.60 \pm 7.67$ & $1.08 \pm 0.11$ & $227.99 \pm 106.17$ & $0.17 \pm 0.014$ & $5.55 \pm 0.44$ & $12.60 \pm 5.56$ \\
\hline & Desiccation & $25.97 \pm 3.90$ & $1.12 \pm 0.02$ & $290.50 \pm 44.14$ & $0.18 \pm 0.032$ & $5.97 \pm 0.90$ & $17.53 \pm 4.72$ \\
\hline & Significance & $*$ & ns & $*$ & $\mathrm{~ns}$ & ns & * \\
\hline \multirow{3}{*}{ Total plant } & Cover crops & $83.58 \pm 27.85$ & & $801.59 \pm 310.71$ & & & $\begin{array}{l}45.63 \pm 18.81 \\
60.27 \pm 17.09\end{array}$ \\
\hline & Desiccation & $111.16 \pm 19.42$ & & $1006.52 \pm 134.32$ & & & \\
\hline & Significance & $*$ & & * & & & * \\
\hline Leaves & & $283.92 \pm 76.04$ & $1.62 \pm 0.12$ & $4557.78 \pm 992.04$ & $0.26 \pm 0.059$ & $8.71 \pm 2.06$ & $410.32 \pm 167.99$ \\
\hline Shoots & & $86.33 \pm 23.12$ & $1.44 \pm 0.03$ & $1245.44 \pm 330.42$ & $0.30 \pm 0.005$ & $10.09 \pm 0.16$ & $126.02 \pm 35.17$ \\
\hline Roots & & $45.82 \pm 24.23$ & $1.09 \pm 0.04$ & $507.38 \pm 279.92$ & $0.22 \pm 0.042$ & $7.33 \pm 1.50$ & $38.67 \pm 27.25$ \\
\hline Total & & $416.06 \pm 123.18$ & & $6310.60 \pm 1602.38$ & & & $575.01 \pm 230.41$ \\
\hline
\end{tabular}

$\mathrm{ns}, *=\mathrm{F}$ values non-significant $(\mathrm{p}>0.05)$ and significant $(\mathrm{p}<0.05)$, respectively; mean \pm standard errors 
Values of $\%$ Ndff in grapevines were about half the amount of those observed by Menino et al. (2007) for 1-year-old orange trees in clean rows of cover crops, but were higher than measurements taken by Neto et al. (2008) for 1 to 3 -year-old pear trees grown in rows with natural cover crops. Besides the probable competition among plant species, the small root development of perennial plants and their low capacity for water and nutrient uptake also explain the low ${ }^{15} \mathrm{~N}$ recovery by plants. In this study, fertilizer $\mathrm{N}$ recovered by cover crops $(26.13 \% \mathrm{Ndff})$ was slightly higher than the estimated for grapevines (Table 4), showing the competition by natural cover crops for mineral $\mathrm{N}$ fertilizer. Low recovery of mineral $\mathrm{N}$ applied to the soil, especially in high doses was also observed by Lobos Ortega et al. (2016) in pasture of southern Chile. The highest atom $\% 15 \mathrm{~N}$ excess and $\% \mathrm{Ndff}$ in topsoil layers in both treatments, as well as higher concentration in the deeper layers with presence of natural vegetation could be explained by the organic ${ }^{15} \mathrm{~N}$ compounds exuded by grapevine and cover crop roots, the decomposition of senescent labeled roots, or by a small amount of urea $-{ }^{15} \mathrm{~N}$ leached down the soil profile favored by the light texture (Lorensini et al., 2012). However, the total amount of ${ }^{15} \mathrm{~N}$ recovered in the soil profile was low for both treatments.

Table 5. Total N, atom $\%{ }^{15} \mathrm{~N}$ excess and $\mathrm{N}$ derived from fertilizer (\%Ndff) in the soil at different depths, under cover crops or desiccation with herbicide application.

\begin{tabular}{|c|c|c|c|c|}
\hline Depth (cm) & & Total N (\%) & Atom $\%{ }^{15} \mathrm{~N}$ excess & Ndff $(\%)$ \\
\hline \multirow{3}{*}{$0-5$} & Cover crops & $0.051 \pm 0.000$ & $0.051 \pm 0.020$ & $1.713 \pm 0.679$ \\
\hline & Desiccation & $0.052 \pm 0.003$ & $0.056 \pm 0.028$ & $1.870 \pm 0.940$ \\
\hline & Significance & ns & ns & ns \\
\hline \multirow{3}{*}{$5-10$} & Cover crops & $0.049 \pm 0.004$ & $0.018 \pm 0.006$ & $0.601 \pm 0.209$ \\
\hline & Desiccation & $0.051 \pm 0.015$ & $0.008 \pm 0.001$ & $0.260 \pm 0.019$ \\
\hline & Significance & ns & * & * \\
\hline \multirow{3}{*}{$10-20$} & Cover crops & $0.048 \pm 0.009$ & $0.007 \pm 0.004$ & $0.241 \pm 0.122$ \\
\hline & Desiccation & $0.043 \pm 0.005$ & $0.004 \pm 0.000$ & $0.147 \pm 0.007$ \\
\hline & Significance & ns & ns & * \\
\hline \multirow{3}{*}{$20-30$} & Cover crops & $0.037 \pm 0.004$ & $0.007 \pm 0.003$ & $0.240 \pm 0.113$ \\
\hline & Desiccation & $0.036 \pm 0.002$ & $0.003 \pm 0.000$ & $0.100 \pm 0.004$ \\
\hline & Significance & ns & ns & * \\
\hline \multirow{3}{*}{$30-40$} & Cover crops & $0.038 \pm 0.009$ & $0.007 \pm 0.004$ & $0.239 \pm 0.126$ \\
\hline & Desiccation & $0.033 \pm 0.004$ & $0.003 \pm 0.001$ & $0.100 \pm 0.021$ \\
\hline & Significance & ns & ns & * \\
\hline \multirow{3}{*}{$40-50$} & Cover crops & $0.031 \pm 0.002$ & $0.004 \pm 0.001$ & $0.134 \pm 0.021$ \\
\hline & Desiccation & $0.026 \pm 0.000$ & $0.003 \pm 0.000$ & $0.099 \pm 0.015$ \\
\hline & Significance & ns & ns & * \\
\hline \multirow{3}{*}{$50-60$} & Cover crops & $0.027 \pm 0.002$ & $0.005 \pm 0.001$ & $0.153 \pm 0.042$ \\
\hline & Desiccation & $0.027 \pm 0.003$ & $0.004 \pm 0.002$ & $0.123 \pm 0.071$ \\
\hline & Significance & ns & ns & * \\
\hline
\end{tabular}

$\mathrm{ns}, *=\mathrm{F}$-values non-significant $(\mathrm{p}>0.05)$ and significant $(\mathrm{p}<0.05)$, respectively; mean \pm standard error. 


\section{Conclusions}

The seasonal response of grapevine to mineral $\mathrm{N}$ depended on plant age. Recently transplanted grapevines exhibited a higher dry matter yield when grown associated with natural vegetation in planting rows, whereas grapevines grown with desiccated cover crops showed lower dry matter yield, but had a higher ${ }^{15} \mathrm{~N}$ concentration in shoots. Older grapevines (12 months old in the second collection) did not show a significant difference in \%Ndff when planted in rows with or without with vegetation, although the total dry matter yield was higher under cover crop desiccation, perhaps due to a probable lower competition for soil water and nutrients. Nitrogen derived from the fertilizer applied to the soil in the presence or absence of cover crops was mainly concentrated in the newly-formed vegetative grapevine organs (leaves and shoots), but most $\mathrm{N}$ in all plant organs was derived from sources other than the fertilizer $\mathrm{N}$ applied in the season.

\section{Conflicts of interest}

The authors declare no financial or other competing conflicts of interest.

\section{Acknowledgements}

We would like to thank the Coordenação de Aperfeiçoamento de Pessoal de Nível Superior (Coordination for the Improvement of Higher Education Personnel) - CAPES (Edital 034/2007) for the scholarships and other financial resources and the Conselho Nacional de Desenvolvimento Cientifico e Tecnológico (Brazilian National Council for Scientific and Technological Development) - CNPq for granting scholarships to the first and third authors.

\section{References}

Abrantes, J.R.C.B., Lima, J.L.M.P., Montenegro, A.A.A. 2015. Desempenho da modelagem cinemática do escoamento superficial para chuvas intermitentes em solos com cobertura morta. R. Bras. Eng. Agríc. Ambiental. 19, 166-172.

Barlow, K., Bond, W., Holzapfel, B., Smith J., Hutton, R. 2009. Nitrogen concentrations in soil solution and surface run-off on irrigated vineyards in Austrália. Australian J. Grap. Wine Research. 15, 131-143.

Brunetto, G., Kaminski, J., Melo, G.W.B., Brunning, F.S., Malmman, F. 2006a. Destino do nitrogénio em videiras Chardonnay e Riesling Renano, quando aplicado no inchamento das gemas. R. Bras. Frut. 28, 497-500.

Brunetto, G., Kaminski, J., Melo, G.W.B., Rheinheimer, D.S. 2006b. Distribuição do nitrogénio fornecido a videirasjovens. Pesq. Agro. Bras. 41, 1299-1304.

Brunetto, G., Ventura, M., Scandellari, F., Ceretta, C.A., Kaminski, J., Melo, G.W.B., Tagliavini, M. 2011. Nutrients release during the decomposition of mowed perennial ryegrass and white clover and its contribution to nitrogen nutrition of grapevine. Nutr. Cycl. Agroecosyst. 90, 299-308.

Brunetto, G., Ceretta, C.A., Melo, G.W.B., Kaminski, J., Trentin, G., Girotto, E., Ferreira, P.A., Miotto, A., Trivelin, P.C.O. 2014. Contribution of nitrogen from agricultural residues of rye to 'Niagara Rosada' grape nutrition. Sci. Hortic. 169, 66-70.

Cardoso, D.P., Silva, M.L.N., Carvalho, G.J., Freitas, D.A.F., Avanz, J.C. 2013. Espécies de plantas de cobertura no recondicionamento químico e físico do solo. Rev. Bras. Ciênc. Agrar. 8, 375-382.

Celette, F., Findeling, A., Gary, C. 2009. Competition for nitrogen in an unfertilized intercropping system: The case of an association of grapevine and grass cover in a Mediterranean climate. Eur. J. Agron. 30, 41-51. 
Conradie, W.J. 1990. Distribution and translocation of nitrogen absorbed during at spring by twoyear-old grapevines grown in sand culture. Am. J. Enol. Vitic. 41, 241-250.

CQFS-RS/SC - Comissão de química e fertilidade do solo. 2004. Manual de adubação e calagem para os estados do Rio Grande do Sul e Santa Catarina. Porto Alegre. SBCS/Núcleo Regional Sul. 400p.

EMBRAPA-Empresa Brasileira de Pesquisa Agropecuária-CNPS .1997. Manual de métodos de análise de solos. Embrapa Solos, Rio de Janeiro, 212p.

Ferreira, D.F. 2011. SISVAR: a computer statistical analysis system. Ci. Agrotecnol. 35, 1039-1042.

Giese, G., Velasco-Cruz, C., Roberts, L., Heitman, J., Wolf, T.K. 2014. Complete vineyard floor cover crops favorably limit grapevine vegetative growth. Sci. Hortic. 170, 256-266.

Glad, C., Farineau, J., Regnard, J.L., Morot-Gaudry, J.L. 1994. The relative contribution of nitrogen originating from two seasonal $15 \mathrm{~N}$ supplies to the total nitrogen pool present in the bleeding sap and in whole Vitis vinifera cv. Pinot noir grapevines at bloom time. Am. J. Enol. Vitic. 45, 327-332.

Köppen, W., Geiger, R. 1928. Klimate der Erde. Gotha: Verlag Justus Perthes. Wall-map $150 \mathrm{~cm} \times 200 \mathrm{~cm}$.

Landan, S., Jacinthe, P-A. 2017. Nitrogen availability and early corn growth on plowed and no-till soils amended with different types of cover crops. J. Soil Sci. Plant Nutr. 17, 74-90.

Lobos Ortega, I., Alfaro, M., Martinez-Lagos, J. 2016. Soil nitrogen contribution to grasslands yield in southern Chile its implications for nitrogen use efficiency nitrogen use efficiency. J. Soil Sci. Plant Nutr. 16, 310-322.
Lorensini, F., Ceretta, C.A., Girotto, E., Cerini, J.B., Lourenzi, C.R., De Conti, L., Trindade, M.M., Melo, G.W., Brunetto, G. 2012. Lixiviação e volatilização de nitrogênio em uma Argissolo cultivado com videira submetida à adubação nitrogenada. Ci. Rural. 42, 1173-1179.

Menino, M.R., Carranca, C., Varennes, A. 2007. Distribution and remobilization of nitrogen in young non-bearing orange trees grown under Mediterranean conditions. J. Plant Nutrition. 30, 10831096.

Neto, C., Carranca, C., Clemente, J., de Varennes, A. 2008. Nitrogen distribution, remobilization and re-cycling in young orchard of non-bearing 'Rocha' pear trees. Sci. Hortic. 118, 299-307.

Pérez-Álvarez, E.P., Garde-Cerdán, T., Santamaría, P., García-Escudero, E., Peregrina, F. 2015. Influence of two different cover crops on soil $\mathrm{N}$ availability, $\mathrm{N}$ nutritional status, and grape yeast-assimilable $\mathrm{N}$ (YAN) in a cv. Tempranillo vineyard. Plant Soil. 390, 143-156.

Rumpel, C., Crème, A., Ngo, P.T., Velásquez, G., Mora, M.L., Chabbi, A. 2015. The impact of grassland management on biogeochemical cycles involving carbon, nitrogen and phosphorus. J. Soil Sci. Plant Nutr. 15, 353-371.

Singh, J., Kunhikrishnan, A., Bolan, N.S., Saggar, S. 2013. Impact of urease inhibitor on ammonia and nitrous oxide emissions from temperate pasture soil cores receiving urea fertilizer and cattle urine. Sci. Tot. Environ. 465, 56-63.

Soil Survey Staff. 2006. Soil taxonomy: a basic system of soil classification for making and interpreting soil surveys, $2^{\text {nd }} e d n$. US Government Printing Office, Washington DC, 333p 
Tedesco, M.J., Gianello, C., Bissani, C.A., Bohnen, H., Volkweiss, S.J. 1995. Análises de solo, planta e outros materiais. 2nd. ed. (Boletim técnico, 5), Porto Alegre, Universidade Federal do Rio Grande do Sul.

Zapata, C., Deléens, E., Chaillou, S., Magné, C. 2004. Partitioning and mobilization of starch and $\mathrm{N}$ reserves in grapevine (Vitis vinifera L.). J. Plant Phys. 161, 1031-1040.
Zuo, Y., Zhang, F. 2008. Iron and zinc biofortification strategies in dicot plants by intercropping with gramineous species. A review. Agron. Sust. Develop. 29, 63-71. 